\title{
Business coaching: Implementation of the push strategy and digital marketing improvement in an Indonesian MSME restaurant during the COVID-19 pandemic
}

\author{
F. Amelita \& H. Suhaimi \\ Faculty of Business and Economics, University of Indonesia, Indonesia
}

\begin{abstract}
The increasing number of micro, small, and medium enterprises (MSMEs) in Indonesia has contributed positively to Indonesia's economy. However, many MSMEs are unable to successfully manage their business. To address this issue, this study was conducted focusing on an Indonesian MSME restaurant that was experiencing difficulties in managing its business during the pandemic. It aims to identify and analyze the MSME's push strategy and digital marketing promotional activities and to find solutions to improve its strategy and marketing promotion. One of the obstacles was in managing its marketing strategy and activities by implementing a strategy to increase its promotion. The data were collected using business coaching methods and qualitative research to investigate the actual condition and problems. Later, the actions that were approved by the MSME were taken to overcome the problems. After conducting several external and internal analyses, a push strategy was applied to increase consumers' awareness of the MSME's products. In addition, MSME's digital marketing promotion through Instagram and a website was optimized to promote its products. It was proven that the promotion successfully improved their exposure and customer engagement.
\end{abstract}

\section{INTRODUCTION}

According to the Indonesian Young Entrepreneurs Association, the COVID-19 pandemic has affected the culinary industry and has decreased its turnover by $30 \%$ (Hamdani, 2020). Bunda Bread, which was established in 2017, is an example of the MSMEs that were competing in the food and beverage sector during COVID-19. Entrepreneurs want their business to grow so that the business could continue to run. Attracting new customers is important for small and medium enterprises to sustain future business growth (Klaassen, 2016). However, MSMEs are challenged to find a method for building awareness to accelerate their business growth during the pandemic. According to Satell (2015), to build awareness, a brand could focus on a push strategy. The push strategy is used to promote products to get consumer attention. To increase customer awareness that is affected by the pandemic, Bunda Bread could add promotional activities by giving product information and services to customers. MSMEs are generally not widely known because their primary marketing relies on word of mouth without maximizing digital marketing through social media, including Instagram and websites. Increasingly developing technology has greatly affected marketing practices in various parts of the world. As a result, digital marketing and traditional marketing began to be integrated. In this transitional era, for the integration of digital and traditional marketing, a new marketing approach is needed, known as Marketing 4.0 (Kotler et al., 2016).

Although there are many problems faced by MSMEs, this study only focuses on the improvement of several aspects that are important and feasible for culinary MSMEs to improve, namely, push strategy and digital marketing. The push strategy could increase customer awareness, which can significantly affect product improvement. Meanwhile, digital marketing promotion through social 
media is considered one of the most cost-effective methods to generate exposure, increase upselling, build a partnership, and improve customer engagement. Based on the mentioned background, this study aims to (1) identify and analyze the actual condition of the MSME's push strategy and digital marketing promotion activities and (2) seek and implement the feasible solution to improve the MSME's push strategy and digital marketing promotion.

\section{LITERATURE REVIEW}

\subsection{Push strategy}

Belch and Belch (2003) defined a push strategy as a way to push products made by a company through distribution channels that they use aggressively to sell and promote to the consumers. One example of a push strategy is to use personal selling by salesmen. According to the Corporate Finance Institute (2020), the push strategy refers to a strategy in which a company tries to bring its products to consumers and 'push' these products to them. It is usually used to receive and increase product exposure, product demand, and consumer awareness. An example of using a push strategy is to bring the products to the consumers. The consumers are introduced to, or reminded of, the products through one of several available marketing methods, such as point of sale (POS) displays and direct selling to customers.

\subsection{Digital marketing}

Digital marketing is a term used to describe all marketing activities that utilize digital channels to promote products (Batra \& Keller, 2016). Channels that are commonly used are websites, search engine marketing, social media marketing, content marketing, email marketing, mobile marketing, and banner advertising. Digital media are used as a tool to promote products to increase brand awareness.

\subsubsection{Instagram}

Instagram is a great medium for advertising because it can tell a story about a product or brand in a visually interesting way (Ištvanic et al., 2017). According to Macharty (2018), an easy method to attract Instagram followers is by maximizing the 150 word limit on the Instagram bio. Instagram users should put a website or point-of-sale place on their profile page that could be visited with just one click. In addition, the profile picture on the Instagram page is also important; it should not show only a blank image. It is also suggested to use a caption on each photo update to describe the brand personality and its unique tone of voice. In addition, placing a hashtag (\#) in the description would place the uploaded photo with other photos containing the same hashtag and turn the hashtag into a clickable link that displays the associated set of photos. Then, the most important thing about content on an Instagram profile is to post a bright and sharp photo. On Instagram, all contents have a single personality that coordinates to all content. Therefore, to coordinate all the content, it is necessary to have a planogram that could tell a story about the brand value.

\subsubsection{Website}

A website is a form of online marketing. If the company website is prepared properly, it would be easier to be found on search engines, such as Google, and would be accessible to consumers who have purchasing intention (McPheat, 2011). Companies can use the 7C framework as a guide for designing a customer interface (CI) when creating a website, namely, context, content, community, customization, communication, connection, and commerce (Rayport \& Jaworski, 2001). 


\section{RESEARCH METHODOLOGY}

This study employed a descriptive and qualitative method and also used a business coaching method. Both the primary and secondary data were acquired from interviews, observations, and Bunda Bread's internal data. The business coaching was implemented for one year through four steps, namely, (1) internal and external analysis; (2) TOWS, gaps analysis, and Pareto analysis; (3) alternative solutions and decision making; and (4) implementation and monitoring.

\section{RESULTS AND DISCUSSION}

Several tools and frameworks were utilized to analyze internal and external factors to get a clearer insight into Bunda Bread's actual business condition. In addition, given the owner's expectations, it was crucial to gain customer awareness during COVID-19. Interviews were conducted to understand not only the customer perspective but also customer needs. Delivering information on the products and services to customers has not been carried out properly. Based on observation, Bunda Bread's marketing only relied on word of mouth without maximizing the use of existing brochures and digital marketing; websites and the Instagram account were not maintained. During the COVID-19 pandemic, business opportunities could still be exploited by utilizing technology, so that MSMEs could still serve customers without them having to leave the house. According to the results of several analyses that were conducted, there are several strategies developed using the TOWS matrix, Gap analysis, and Pareto analysis: (1) implementation of the push strategy and (2) carrying out their promotional activities through online channels, especially Instagram and website, that is, digital marketing improvement.

\subsection{Implementation of the push strategy}

The implemented push strategy makes it easier to communicate with customers because the customer could independently find out the details of the product on the products for sale display which is located at the bread display. Employees also expressed the convenience of having a products for sale display related to conditions in Jakarta that were not conducive due to COVID-19, so that the sellers could also maintain a safe distance from the customers while selling. Similar to the implementation of direct selling, provision of brochures and also improvements to the GoFood display encouraged informed customers to order bread in the future and place orders using GoFood. Based on these conditions, a push strategy can be continued to gain more benefits. However, due to time constraints, direct selling as part of a push strategy requires supervision to maintain the communication between the employee and the customers considering what information that must be provided and obtained.

\subsection{Digital marketing improvement}

Changing Bunda Bread's personal Instagram account to a business account enabled Instagram Insights. It was found that Bunda Bread's Instagram has created 735 impressions, 131 profile visits, and 18 website visits in a week. Based on the improvement results of Bunda Bread's Instagram profile structure, the increase in digital marketing through Instagram improvements had been achieved from their engagement on Instagram. Additionally, its followers have increased from 102 to 875 . Besides Instagram, the results of the Google Business report showed that the increase in digital marketing through website improvements had been achieved from the engagement on their website. After making improvements to the website, it was found that the viewers increased from 263 to 2,500. Of the 2,500 views, 780 views were using Google, and 1,700 were using Google Maps. This finding proves that Bunda Bread's Instagram and website are worthy of customers' participation because they provided useful information for the customers. 


\section{CONCLUSION}

Through business coaching, it was revealed that Bunda Bread had several problems that were typically faced by an MSME during the COVID-19 pandemic. Studies found that the push strategy developed a method that can respond to the market by providing approaches to acquire customers, which begins with building product awareness. Further, Bunda Bread's digital marketing, including its Instagram and website exposure and engagement, has improved. Based on the results, this study is expected to provide additional insights into the application of the push strategy and digital marketing strategy in MSMEs, especially in the restaurant sector during COVID-19.

Based on external and internal analyses, Bunda Bread, an MSME, was facing several issues in its financial reporting system, human resources management, and operational facilities. However, this study only focuses on marketing aspects. Thus, other issues can be improved by other future studies to leverage the MSMEs' position among their competitors.

\section{REFERENCES}

Batra, R., \& Keller, K. L. (2016). Integrating marketing communications: New findings, new lessons, and new ideas. Journal of Marketing, 80(6), 122-145.

Belch, G. E., \& Belch, M. A. (2003). Advertising and promotion: An integrated marketing communications perspective. The McGraw- Hill.

Corporatefinanceinstitute.com. (2020). Push Marketing Strategy. Corporatefinanceinstitute.com. Retrieved from https://corporatefinanceinstitute.com/resources/knowledge/strategy/push-marketing-strategy/ (accessed 20 August 2020).

Hamdani, Trio. (2020). Restoran hingga Kedai Kopi Terancam Gulung Tikar Imbas Corona. Finance.detik.com. Retrieved from https://finance.detik.com/berita-ekonomi-bisnis/d- 4943285/restoran-hingga-kedai-kopiterancam-gulung-tikar-imbas-corona (accessed 20 June 2020).

Ištvanic, M., Crnjac Milic, D., \& Krpic, Z. (2017). Digital marketing in the business environment. International journal of electrical and computer engineering systems, 8(2.), 67-75.

Klaassen, T. J. H. (2016). How do SMEs attract new Customers to Sustain Future Business growth?: An exploratory study into acquisition practices of small companies (Master's thesis, University of Twente).

Kotler, P., Kartajaya, H., \& Setiawan, I. (2016). Marketing 4.0: Moving from traditional to digital. John Wiley \& Sons.

McPheat, Sean. (2011). Developing Internet Marketing Strategy. USA: Ventus Publishing

Rayport, J. F., \& Jaworski, B. J. (2001). Introduction to E-commerce. New York: McGra- Hill

Satell, Greg (2015). Balancing Push and Pull Marketing. Raconteur.com. Retrieved from https://www. raconteur.net/business-innovation/balancing-push-and-pullmarketing (accessed 12 June 2020). 